\title{
ANALISIS KEPEMIMPINANAN KEPALA KELURAHAN PEREMPUAN DALAM MENINGKATKAN KUALITAS PELAYANAN PUBLIK DI KELURAHAN SUMBERSARI KABUPATEN JEMBER
}

\author{
NUR AINI MAYASIANA* \\ SAVELA MAHATMA IRA SASTI \\ Program Studi Ilmu Administrasi Negara \\ Sekolah Tinggi Ilmu Administrasi Pembangunan Jember \\ *Email: mayasiana30@gmail.com
}

\begin{abstract}
ABSTRAK
Perkembangan suatu bangsa salah satunya dapat dilihat dari sosok pemimpinnya. Pemimpin tidak hanya identik dengan laki-laki saja, akan tetapi sejak abad ke-15 sudah bermunculan perempuan sebagai kepala pemerintahan. Termasuk di Indonesia sendiri perempuan sebagai pemimpin bukan lagi menjadi suatu hal yang aneh karena di Indonesia perempuan juga memiliki hak yang sama seperti laki-laki untuk memimpin dan dipimpin. Kepemimpinan diartikan sebagai kemampuan seseorang dalam mempengaruhi orang lain terlepas dari apakah ia seorang laki-laki ataupun perempuan. Salah satunya ialah figur kepala Kelurahan perempuan yang berhasil menjalankan tugasnya. Hal ini menunjukan bahwa kesenjangan kedudukan antara laki laki dan perempuan dapat di hilangkan. Karakteristik pemimpin perempuan diharapkan akan lebih membawa kemajuan dalam hal meningkatkan mutu kerja organisasi atau instansi yang dipimpinnya, misalkan dalam hal peningkatan pelayanan publik. Penelitian ini merupakan penelitian kualitatif dengan lokasi di kelurahan Sumbersari, kecamatan Sumbersari kabupaten Jember. Fokus penelitian ini adalah menganalisa kepemimpinan kepala kelurahan perempuan di kelurahan

Sumbersari dalam hal peningkatan pelayanan publik. Sumber data penelitian adalah data primer dan data sekunder. Metode pengumpulan data diperoleh melalui observasi, wawancara langsung kepada kepala kelurahan, pegawai kelurahan dan beberapa masyarakat dilingkungan kelurahan Sumbersari sebagai responden serta dokumentasi.
\end{abstract}

Kata Kunci: Kepemimpinan, Perempuan, Kelurahan, Pelayanan Publik 


\section{PENDAHULUAN}

Perkembangan suatu bangsa salah satunya dapat dilihat dari sosok pemimpinnya. Dimasa saat ini pemimpin bukan hanya sebagai sebuah simbol, namun pemimpin juga harus memiliki kemampuan yang mumpuni untuk memimpin. Pemimpin tidak hanya identik dengan laki-laki saja, akan tetapi sejak abad ke-15 sudah bermunculan perempuan sebagai kepala pemerintahan. Hingga pada abad ke21 kepemimpinan gender semakin menjadi trend di berbagai negara. Termasuk di Indonesia sendiri perempuan sebagai pemimpin bukan lagi menjadi suatu hal yang aneh karena di Indonesia perempuan juga memiliki hak yang sama seperti lakilaki untuk memimpin dan dipimpin. Kepemimpinan seorang perempuan sekarang ini bisa disejajarkan dengan kepemimpinan seorang laki-laki baik dalam kinerja maupun dalam melayani masyarakat. Perempuan yang mulanya hanya dipadang sebelah mata dan diragukan dalam memipin sekarang dipandangan positif oleh masyarakat.
Pemimpin adalah faktor utama dalam menentukan suatu tujuan yang akan dicapai dalam suatu organisasi atau negara. Kepemimpinan adalah suatu alat atau proses untuk mempengaruhi orang agar bersedia melakukan suatu tindakan secara sukarela. Selain itu karakter seorang pemimpin akan berdampak pada kinerja yang dipimpinnya, dalam artian seorang pemimpin akan menjadi panutan bagi anggotanya,sehingga dibutuhkan seorang pemimpin yang dapat menjadi panutan agar tujuan dari organisasi tersebut dapat tercapai.

Peran pemimpin sesungguhnya sangat strategis tidak hanya dalam berorganisasi namun juga dalam mewujudkan kesejahteraan masyarakat luas. Hal ini dikarenakan pemimpin dapat menentukan ke arah mana dan langkah-langkah untuk mencapai tujuan dengan mengkoordinir para anggotanya. Baik dan buruknya sifat pemimpin akan berpengaruh dalam pencapaian target kerja atau visi misi yang sudah dicanangkan. 
Banyak pendapat yang dapat menentukan sosok pemimpin yang ideal. Dalam memandang figur pemimpin tak lepas dari sisi subyektivitas sehingga sangat beragam kriteria pemimpin yang ideal. Di antara banyaknya kriteria tentang sosok pemimpin, sebenarnya Pancasila mempunyai kriteria tersendiri terkait sosok pemimpin sendiri. Pancasila sebagai falsafah bangsa sudah memberikan contoh asas-asas utama dalam kepemimpinan yang berorientasi dalam memberikan pelayanan kepada orang lain.

Pemimpin adalah pelayan publik yang memberikan pelayanan kepada orang lain, termasuk kepada bawahan akan semakin menumbuhkan keterikatan yang kuat antara pimpinan dan juga bawahan. Keterikatan antara pemimpin dan bawahan tadi akan memberikan dampak yang positif dalam pelaksanaan tugas dan tanggung jawab karena memiliki satu pemahaman yang sama dalam memberikan layanan tentunya akan memudahkan dalam memberikan pelayanan kepada masyarakat.
Publik membutuhkan pemimpin pelayan. Percepatan perbaikan kualitas pelayanan dimulai dari komitmen pemimpin. Tanpa adanya komitmen pemimpin, tak mungkin pelayanan publik ke masyarakat dapat berkualitas. Sejak diterbitkannya UU 25/2009 tentang Pelayanan Publik hingga saat ini masih banyak pemimpin organisasi penyelenggara pelayanan publik yang belum mematuhi dan menerapkan setiap ketentuan yang terdapat dalam Undang-undang tersebut.

Jika seorang pemimpin sangat menyadari bahwa tugas utamanya adalah memberikan pelayanan kepada publik, kesejahteraan masyarakat pasti akan bisa dicapai. Karena prinsip kepemimpinan yang diterapkan akan selalu berorientasi pada kepuasan masyarakat. Sosok pemimpin berpengaruh dalam pelayanan khususnya dalam organisasi penyelenggara pelayanan publik, bisa dipastikan jika pemimpin terjun langsung dalam pelayanan publik maka akan ada perbaikan pola kerja yang 
mengedepankan pelayanan terbaik kepada masyarakat.

Sebagimana peran pemimpin Kelurahan atau kepala kelurahan sebagai seorang pemimpin yang berkecimpung langsung dalam pelayanan masyarakat, mulai dari pelayanan dalam bentuk pengaturan atau pun pelayanan-pelayanan lain dalam rangka mencapai kesejahteraan masyarakat. Pelayanan masyarakat pada dasarnya adalah berkaitan dengan peningkatan kualitas pelayanan itu sendiri. Pelayanan yang berkualitas sangat tergantung pada berbagai aspek, yaitu bagaimana pola penyelenggaraannya (tata laksana), dukungan sumber daya manusia, dan kelembagaan.

Fungsi dan peran antara laki-laki dan perempuan itu berbeda. Pembedaan fungsi dan peran antara laki-laki dan perempuan itu tidak ditentukan karena keduanya terdapat perbedaan biologis atau kodrat, melainkan dibedakan menurut kedudukan, fungsi, dan peranan masing-masing dalam berbagai bidang kehidupan dan pembangunan. Pembedaan itu disebut dengan "gender". Meskipun ada perbedaan antara laki-laki dan perempuan dalam hal kedudukan, fungsi dan peran. Tetapi ada persamaan dalam hal kedudukan, baik laki-laki maupun perempuan yang sama-sama berkedudukan sebagai subjek atau pelaku pembangunan.

Kedudukan sebagai subjek pembangunan, laki-laki dan perempuan mempunyai peranan yang sama dalam merencanakan, melaksanakan, memantau dan menikmati hasil pembangunan. Hak yang sama dibidang pendidikan misalnya, anak laki-laki dan perempuan mempunyai hak yang sama untuk dapat mengikuti pendidikan sampai ke jenjang pendidikan formal tertentu. Tentu tidaklah adil, jika dalam era yang seperti ini menomorduakan pendidikan bagi perempuan, apalagi jika anak perempuan mempunyai kecerdasan atau kemampuan maka sangat dianjurkan perempuan melanjutkan kejenjang yang lebih tinggi.

Pengembangan peran kaum perempuan dalam kegiatan pembangunan sudah banyak 
dilakukan, bahkan sudah masuk dalam penyelenggaraan pemerintahan di tingkat kelurahan atau desa. Sudah banyak kepala kelurahan atau desa di Indonesia yang disandang oleh kaum perempuan. Dalam menjalankan tugas dan kewajiban sebagai “manajer" pemerintahan kelurahan atau desa, tentunya banyak hambatan, godaan dan tantangan yang harus dilalui oleh mereka. Namun demikian tidak sedikit kelurahan atau desa perempuan mencapai prestasi yang lebih berhasil ataupun gemilang dalam melaksanakan pekerjaan mereka.

Pemimpin perempuan dalam suatu kelurahan atau desa bukan suatu hal yang aneh lagi, sebagimana di Kelurahan Sumbersari salah satunya merupakan kelurahan yang dipimpin oleh perempuan hingga saat ini. Kelurahan Sumbersari

\section{TINJAUAN PUSTAKA}

\subsection{Teori Kepemimpinan}

Teori kepemimpinan membicarakan bagaimana seorang menjadi pemimpin, atau bagaimana timbulnya seorang pemimpin. terletak di Kecamatan Sumbersari Kabupaten Jember. Kantor Kelurahan Sumbersari melayani masyarakat dalam memenuhi kebutuhan administrasi kependudukan, termasuk di antaranya perizinan-perizinan seperti pekerjaan umum, perizinan umum kelurahan, perizinan pendidikan, kesehatan warga kelurahan Kantor Kelurahan Sumbersari, perumahan, penataan ruang, perhubungan, lingkungan hidup, pertanahan yang menjadi kewenangan daerah, serta pemberdayaan perempuan dan perlindungan anak.

Berdasarkan latar belakang diatas, maka penulis terdorong untuk melakukan penelitian dengan judul: “Analisis Kepemimpinanan Kepala Kelurahan Perempuan Dalam Meningkatkan Kualitas Pelayanan Publik di Kelurahan Sumbersari Kabupaten Jember”.

Beberapa teori kepemimpinan diantaranya sebagai berikut:

a. Teori Sifat

Teori ini penekanannya lebih pada sifat-sifat umum 
yang dimiliki pemimpin, yaitu sifat-sifat yang dibawa sejak lahir. Menurut teori sifat, hanya individu yang memiliki sifat-sifat tertentulah yang bisa menjadi pemimpin.

b. Teori Perilaku

Teori ini lebih terfokus pada tindakan-tindakan yang dilakukan pemimpin daripada memperhatikan atribut yang melekat pada diri seorang pemimpin. Dasar pemikiran teori ini adalah kepemimpinan merupakan perilaku seseorang ketika melakukan kegiatan pengarahan suatu kelompok kearah pencapaian tujuan.

c. Teori Situasional

Teori ini mengatakan bahwa pembawaan yang harus dimiliki seorang pemimpin adalah berbeda-beda, tergantung dari situasi yang sedang dihadapi.

d. Teori Jalan Tujuan

Menurut teori ini, nilai strategis dan keefektifan seorang pemimpin

didasarkan pada

kemampuannya dalam

menimbulkan kepuasan dan motivasi anggotanya dengan penerapan hadiah.

e. Teori Kelebihan

Teori ini beranggapan bahwa seseorang akan menjadi pemimpin apabila ia memiliki kelebihan dari para pengikutnya.

f. Teori Kharismatik

Kharisma diperoleh dari kekuatan yang luar biasa. Pemimpin yang bertipe kharismatik biasanya memiliki daya tarik, kewibawaan dan pengaruh yang sangat besar.

\subsection{Kepemimpinan Perempuan}

Beberapa konsep pengertian tentang perempuan dan laki-laki yang diungkapakan beberapa tokoh, maka timbul perbedaan antara lakilaki dan perempuan secara alami (biologis) dalam berbagai konteks budaya seringkali mendasari deferensiasi peran (divison of labor) yang ada. Akibatnya sering terjadi 
ketidakseimbangan peran antara lakilaki dan perempuan yang dalam beberapa kasus dapat memunculkan adanya dominasi laki-laki dan perempuan. Laki-laki dengan ciri biologinya serta sifat-sifat senantiasa diidentikkan dengan orientasi instrumental, yakni aktif, penonjolan diri, pelindung, dan pemimpin. Perempuan dengan ciri-ciri biologisnya diidentikkan dengan sifat emosional seperti pasif, berkorban untuk feminim, yakni berkaitan dengan orientasi keperluan orang lain, tergantung pemberi cinta, dan pengasuh.

\subsection{Kelurahan}

Sesuai dengan Peraturan Pemerintah Nomer 73 Tahun 2005 tentang Kelurahan, Kelurahan adalah wilayah kerja Lurah sebagai perangkat daerah kabupaten/kota dalam wilayah Kecamatan.

\subsection{Pelayanan Publik}

Dalam kamus Bahasa Indonesia (1990), pelayanan publik dirumuskan sebagai berikut: a. Pelayanan adalah perihal atau cara melayani.

b. Pelayanan adalah kemudahan yang diberikan sehubungan dengan jual beli barang dan jasa.

c. Pelayanan medis merupakan pelayanan yang diterima seseorang dalam hubungannya dengan pensegahan, diagnosa dan pengobatan suatu gangguan kesehatan tertentu.

d. Publik berarti orang banyak (umum).

\subsection{Kualitas Pelayanan}

Pengertian kualitas Pelayanan Pemberian pelayanan yang baik merupakan salah satu upaya instansi/organisasi untuk menciptakan kepuasan bagi konsumen/ masyarakatnya. Jika konsumen/ masyarakatnya merasa telah mendapatkan pelayanan yang baik berarti instansi/organisasi mampu memberikan pelayanan yang baik pula. 


\section{METODE PENELITIAN}

Penelitian ini memiliki fokus utama yakni perempuan dalam peranannya di sektor publik, perempuan dalam sektor publik tersebut bertindak sebagai pemegang jabatan struktural di pemerintahan. Penelitian ini berfokus dalam dengan menggambarkan, yaitu: pengarahan, koordinasi, komunikasi, pengambilan keputusan, pengawasan.

Lokasi penelitian adalah Kantor Kelurahan Sumbersari yang beralamat di Jalan Halmahera Kabupaten Jember. Informan dalam penelitian ini ditentukan berdasarkan keperluan dalam peneitian ini. Informan yang diperlukan untuk memperoleh data primer yaitu antara lain: Kepala Kelurahan Sumbersari Jember, pegawai Kelurahan Sumbersari Jember, penduduk di wilayah Kelurahan Sumbersari Jember.

Jenis data yang digunakan dalam penelitian ini adalah data primer yang berupa hasil wawancara yang didapat peneliti dari informan dan data sekunder yang diperoleh dari sumber kedua atau sumber sekunder dari data yang dibutuhkan. Sumber data dalam penelitian ini yaitu narasumber (informan), peristiwa (aktivitas), tempat (lokasi), dan dokumen (arsip).

\section{HASIL PENELITIAN DAN PEMBAHASAN}

\subsection{Deskripsi Objek Penelitian}

Kelurahan Sumbersari

kabupaten Jember yang masuk di dalam wilayah Kecamatan Sumbersari Kabupaten Jember dengan kode Kemendagri 35.09.21. Kelurahan Sumbersari ini memiliki luas $4.88 \mathrm{~km}^{2}$, beralamat jalan Halmahera Kabupaten Jember, Jawa Timur, 68121.
Adapun kewenangan Kantor Kelurahan Sumbersari yang beralamat di Jalan Halmahera Kabupaten Jember ini melayani masyarakat dalam memenuhi kebutuhan administrasi kependudukan, termasuk di antaranya perizinan-perizinan seperti pekerjaan umum, perizinan umum kelurahan, perizinan pendidikan, 
kesehatan warga kelurahan Kantor Kelurahan Sumbersari, perumahan, penataan ruang, perhubungan, lingkungan hidup, pertanahan yang menjadi kewenangan daerah, serta pemberdayaan perempuan dan perlindungan anak.

Kantor kelurahan atau lurah yang berada di wilayah Kabupaten Jember ini melayani izin untuk pengurusan surat keterangan domisili, pengurusan NPWP, Surat Kelakuan Baik, Surat Pindah Keluar, Surat Keterangan Tidak Mampu Kantor Kelurahan Sumbersari, Surat Keterangan Usaha, Surat Usaha Mikro, dan Surat Pernyataan Miskin, surat domisili sementara dan lain sebagainya.

\subsection{Analisa}

Kepemimpinan

Kepala Kelurahan Perempuan ditinjau dari Metode Kepemimpinan sekaligus Tipe dan Gaya Kepemimpinan

Ditinjau dari metode kepemimpinan menurut Ordway (dalam Kartono, 2010), maka metode yang digunakan kepala kelurahan perempuan adalah metode peka terhadap saran-saran. Metode peka terhadap saran-saran yang dimaksud Ordway adalah sifat pemimpin itu harus luwes terbuka, dan peka pada saran-saran yang positif sifatnya. Pemimpin harus menghargai pendapat-pendapat orang lain, untuk kemudian mengkombinasikannya dengan ide-ide sendiri. Hal tersebut dapat digunakan untuk membangkitkan inisiatif kelompok agar memberikan saran-saran yang baik. Seseorang akan merasa senang dan bangga, apabila sarannya diterima, sebaliknya orang bisa tidak terima (jengkel), apabila saransarannya selalu dianggap angin lalu saja dan tidak diperhatikan. Berangkat dari pemaparan tersebut, maka dapat dikatakan metode yang digunakan kepala kelurahan perempauan adalah metode peka terhadap saran-saran. Hal ini dapat dilihat dari menurut pemaparan informan lurah dan perangkat kelurahan yang mengemukakan jika dalam suatu permasalahan atau pengambilan keputusan maka hal tersebut senantiasa di musyawarahkan terlebih dahulu dengan perangkat kelurahan dan karangtaruna sekitar, agar mencapai 
kata mufakat demi kemajuan kelurahan Sumbersari.

Sebagimana menurut bapak Sulistyo (2020) bahwa setiap keputusan yang diambil oleh bu Ani (kepala kelurahan) selalu berdasarkan musyawarah terlebih dahulu, tidak serta merta memutuskan tanpa mendengar pendapat dari pihak lainnya. Wahjosumo (dalam Kartono) terdapat tipe-tipe pemimpin. Selanjutnya terkait tipe dan gaya kepemimpinan kepala kelurahan perempuan di kelurahan Sumbersari ini, pada praktek pemerintahan kepemimpinan kepala kelurahan perempuan termasuk dalam gabungan beberapa tipe, antara lain tipe misionaris, dan tipe developer (pembangunan). Menurut informan kepala kelurahan perempuan memiliki sifat yang ramah, jika ditengah jalan bertemu atau berpapasan dengan warganya kepala kelurahan selalu menegur sapa. Hal ini menunjukan bahwa kepala kelurahan perempuan beranggapan bahwa warga masyarakatnya adalah bagian dari kepemimpinan nya, bukan sekedar pencitraan kepada warga semata.

Kepala kelurahan perempuan juga adalah manusia biasa, namun memiliki kedudukan yang lebih tinggi, dari perempuan lainya. Sebagai orang yang berangkat dari kalangan orang biasa-biasa saja kepala kelurahan perempuan berupaya untuk bersikap merakyat dengan masyarakatnya. Sebagai pemimpin, kepala kelurahan tentunya menjadi panutan bagi bawahanya, bahkan sikapnya turut menjadi sorotan kepemimpinanya. Model, tipe dan gaya kepemimpinanya pun menjadi tolak ukur baik, atau tidaknya seorang pemimpin itu. Kepala kelurahan perempuan kelurahan Sumbersari berupaya agar kepemimpinannya, diterima oleh semua elemen masyarakat dengan model, tipe dan gaya kepemimpinan yang diterapkan dalam kepemimpinanya.

Dalam pandangan politik ataupun agama. Ajaran agama islam telah mengangkat derajat kaum perempuan untuk keluar dari lingkaran setan yang mengangap hina kaum perempuan. Menurut 
sejarah islam keadaan kaum perempuan berubah, seiring makin berkembangnya kesadaran hak kaum perempuan, dan konsep hak juga makin meningkat (Fakih, 2013). Menurut Muhammad (2001) “tidak ada persolan apakah seorang presiden harus laki-laki atau perempuan. Perempuan dapat menjadi preside jika kemaslahatan bangsa menghendakinya. Sebaliknya, seorang laki-laki tidak layak menjadi presiden apabila ia dapat membawa kesengsaraan dan penderitaan rakyatnya". Berdasarkan pendapat tersebut, dapat difahami bahwasanya pemimpin laki-laki maupun perempuan itu sama saja. Tergantung kembali pada pribadi pemimpin tersebut bagaimana mengkoordinir kepemimpinanya dan dalam menjalankan pemerintahanya.

$$
\text { Hal tersebut tentunya }
$$

memberikan peluang kepada kaum perempuan untuk berkiprah di dunia politik. Bahwasanya perempuan juga layak dan mampu menjadi pemimpin. Perempuan yang dianggap lemah, kurang tegas dan tidak bijaksana mampu menjadi pemimpin yang bijaksana dan lemah lembut. Pemahaman laki-laki lebih menonjol dan layak menjadi pemimpin dari pada perempuan tidak lagi menjadi persoalan yang dominan dalam ranah kepemimpinan, hal ini sesuai dengan yang terdapat pada kepemimpinan kepala Kelurahan Sumbersari Kecamatan Sumbersari Kabupaten Jember.

Konsep gender adalah sifat yang melekat pada kaum laki-laki dan perempuan yang dibentuk oleh faktor-faktor sosial maupun budaya, sehingga lahir beberapa anggapan tentang peran sosial dan budaya lakilaki dan perempuan. Bentuk sosial atas laki-laki dan perempuan itu antara lain: kalau perempuan dikenal sebagai mahluk yang lemah lembut, cantik, emosional, atau keibuan. Sedangkan laki-laki dianggap kuat, rasional, jantan dan perkasa. Oleh karena itu dapat dikatakan gender sebagai kosep sosial yang membedakan (dalam arti: memilih atau memisahkan) peran antara lakilaki dan perempuan. Perbedaan fungsi dan peran antara laki-laki dan perempuan itu tidak ditentukan karena antara keduanya terdapat perbedaan biologis atau kodrat, tetapi 
dibedakan atau dipilah-pilah menurut kedudukan, fungsi, dan peran masing-masing dalam berbagai bidang kehidupan dan pembangunan (Handayani dan Sugiarti, 2002).

Menurut informan, dalam penelitian mengemukakan bahwa kepala kelurahan perempaun adalah sosok yang ramah dan lemah lembut. Hal tersebut membuktikan bahwa walaupun kepala kelurahan perempuan adalah seorang pemimpin, akan tetapi kepala kelurahan tidak lupa akan kodrat dan jiwanya sebagai perempuan pada umumnya. Terpilihnya kepala kelurahan perempuan menjadi sebagai pemimpin mencerminkan bahwa posisi perempuan sama dengan laki-laki. Posisi perempuan yang ditempatkan sebagai subdronat laki-laki sesungguhnya muncul dan lahir dari sebuah bangunan masyarakat atau peradapan yang dikuasai laki-laki secara populer dikenal sebagai peradapan patriaki. Budaya patriaki merupakan salah satu faktor dasar yang dianggap mempegaruhi kemunculan pemimpin kaum perempuan di bidang politik. Kepala kelurahan perempuan yang terdapat di kelurahan Sumbersari dengan program PKK yang di koordinatori istri-istri dari perangkat kelurahan membuktikan bahwa kepala kelurahan perempuan, juga peduli dengan kaum perempuan yang terdapat di kelurahan Sumbersari.

Peluang perempuan dalam dunia politik sangat besar, karena saat ini perempuan juga berhak atas pendidikan tinggi, sebagaimana kepala kelurahan Sumbersari Dra. Ani Mujiati, Msi yang merupakan lulusan Magister di Universitas Jember dengan menempuh pendidikan di Fakultas Ilmu Sosial dan Politik. Sehingga mumpuni dalam teori dan praktek dalam mempimpin suatu instansi. Kehadiran kepala kelurahan perempuan merupakan suatu bentuk kesetaraan gender. Memberikan kesempatan kepada perempuan dalam dunia politik. 


\subsection{Kepemimpinan Kepala \\ Kelurahan Perempuan di Tinjau dari Pelayanan \\ Masyarakat di Kelurahan \\ Sumbersari}

Menurut Nurcholis

(2011)

fungsi pemerintahan baik pusat, dearah, maupun kelurahan/desa adalah memberikan pelayanan kepada masyarakat. Pelayanan tersebut terdiri atas pelayanan publik, pelayanan pembangunan, dan pelayanan perlindungan. Pemberian pelayanan tersebut ditunjukan untuk menciptakan kesejahteraan masyarakat. Sebagai seorang pemimpin, kepala kelurahan tentunya memiliki kewajiban umtuk menjalankan tugas yang diembannya. Tugas tersebut dilaksanakan sesuai program kerja bersama perangkat kelurahan lain untuk memajukan dan mensejahterakan warga masyarakat wilayah setempat.

Fungsi pemerintahan sebenarnya tidak luput dari pelayanan kepada masyarakatnya. Hal tersebut merupakan fungsi dari kelurahan itu sendiri, dan merupakan pengabdian terhadap masyarakat. Nurcholis (2011)memaparkan pelayanan pemerintahan kelurahan tersebut berhubungan dengan tiga fungsi yang dimiliki pemerintahan desa/kelurahan: pertama, memberikan pelayanan kepada masyarakat (publik servise funcion); kedua, melakukan pembangunan (development funcion); dan ke tiga, menciptakan ketentraman, ketertiban, dan keamanan masyarakat (protective funcion). Untuk mewujudkan pelayanan tersebut dalam kegiatan kinerja sehari-hari baik pada jam kerja di kantor atau luar kantor, maka kepala kelurahan harus siap saat dibutuhkan.

Berdasarkan teori dari Nursholis (2011) diatas, maka jika diterapkan pada hasil penelitian kepempinan kepala kelurahan perempuan maka dapat disimpulkan sebagai berikut:

a. Pelayanan Perlindungan

Pelayanan perlindungan kepada warga adalah pelayanan yang berupa upaya pemerintah kelurahan memberikan rasa aman dan tentram kepada warganya. Berdasarkan pelayanan perlindungan ini tipe 
kepemimpinan kepala
kelurahan adalah tipe
misionaris.
Pelayanan Publik

Layanan publik adalah pelayanan yang diterima oleh semua orang tanpa seorangpun dikecualikan dalam pelayanannya. Pelayan ini misalnya pemberian surat keterangan untuk pembuatan KTP/SIM/SKCK sertifikat tanah, surat keterangan miskin, surat pengantar untuk mendapatkan pengobatan gratis, dan lainlain.

Sebagimana aktivitas pelayanan umum di Kelurahan Sumbersari yang terus melakukan pembenahan, bahkan warga kelurahan diharapkan tidak sampai menunggu berlamalama untuk mendapatkan pelayanan dari petugas kelurahan. Hal itu dituturkan oleh Dra.Ani Mujiati, MSi (2020) selaku Lurah Sumbersari, bahwa menurut beliau paling tidak dibutuhkan waktu antara 10 sampai 15 menit untuk melayani kebutuhan masyarakat dan semua itu tanpa dipungut biaya alias gratis, asalkan persyaratan yang dibawa oleh masyarakat itu lengkap langsung kita layani, kalau bisa kita permudah kenapa harus dipersulit dan jika berbelit-belit itu akan menyusahkan masyarakat.

Kelurahan Sumbersari setiap harinya tidak pernah sepi dari kunjungan masyarakat, hal itu karena banyak warga yang meminta surat pengantar untuk berbagai macam keperluan, misalkan untuk surat pengantar ke kepolisian, dispenduk dan Kantor Urusan Agama (KUA), sekolah dan lain sebagainya. Sebgaimana menurut Dra.Ani Mujiati, MSi (2020), bahwa warga datang ke Kelurahan Sumbersari untuk membuat berbagai surat pernyataan atau keterangan, diantaranya seperti surat keterangan tidak mampu, surat keterangan usaha, surat keterangan belum pernah memiliki rumah dan lainlainnya.

Hal ini setara dengan apa yang dirasakan oleh warga di kelurahan Sumbersari, yaitu ibu Murdyastuti (2020) warga kelurahan Sumbersari Kecamatan Sumbersari yang 
memberikan pujian terhadap pelayanan di Kelurahan Sumbersari, karena pelayanan terbaik dari

\section{KESIMPULAN DAN SARAN}

\subsection{Kesimpulan}

Hasil penelitian menunjukkan bahwa adanya pengaruh karakteristik pekerjaan dengan kepemimpinan perempuan. Secara umum kepemimpinan yang digunakan oleh Kepala Kelurahan perempuan di kelurahan Sumbersari adalah kepemimpinan demokratis dengan karakter kepribadian yang layak menjadi panutan. Tipe dan Metode kepemimpinan kepala kelurahan perempuan kelurahan Sumbersari Kecamatan Sumbersari Kabupaten Jember yang digunakan kepala kelurahan perempuan dalam menjalankan kepemimpinanya adalah tipe peka terhadap saransaran. Hal ini dilihat dalam pengambilan keputusan kepala kelurahan perempuan selalu mengadakan musyawarah dengan perangkat kelurahan lainnya. Adapun tipe yang digunakan kepala kelurahan perempuan adalah gabungan antara tipe misionaris dan aparatur sipil negara (ASN) sangat dibutuhkan oleh masyarakat.

tipe developer (pembangunan), yang terlihat pada kehidupan seharihari seperti kepala kelurahan selalu melakukan perbaikan terhadap pelayanan kepada masyarakat. Hal ini pun dirasakan oleh masyarakat wilayah kelurahan Sumbersari yang mengaku bahwan pelayanan di kelurahan Sumbersari sangat cepat dan mudah, sehingga warga merasa terbantu oleh kelurahan Sumbersari dalam bebragai kepengurusan terkait administrasi.

\subsection{Saran}

Bawasannya analisa terhadap kepemimpinan kepala kelurahan di kelurahan Sumbersari kecamatan Sumbersari kabupaten Jember ini sudah cukup menggambarkan bahwa tidak ada halangan atau kekawatiran bagi perempuan untuk menjadi pemimpin. Sebagaimana lurah di kelurahan Sumbersari ini telah membuktikan bahwa sosoknya sebagai kepala kelurahan dapat 
menjadi contoh yang baik bagi bawahannya. Hal itu dibuktikannya dengan semakin meningkatnya pelayanan terhadap masyarakat. Hanya saja saran agar lebih meningkatkan pelayanan terhadap

\section{DAFTAR PUSTAKA}

Departemen Pendidikan Nasional. 2011 Kamus Besar Bahasa Indonesia Pusat Bahasa. Jakarta: PT Gramedia Pustaka Utama.

Fakih, Mansoer. 2013. Analisis Gender dan Transfomasi Sosial. Yokyakarta: Pustaka Pelajar.

Fakih, Mansour. 1996. Menggeser Konsepsi Gender dan Transformasi Sosial. Yogyakarta: Pustaka Pelajar.

Hadi Sutrisno. 1980. Metodologi Research I. Yogyakarta: Fakultas Psikologi UGM.

Handayani, Trisakti dan Sugiarti. 2006. Konsep dan Teknik Penelitian Gender. Malang: UMM Press.

Kartono Kartini. 2010. Pemimpin dan Kepemimpinan. Jakarta: Rajawali Pres.

Miles, Mathew B. dan A. Michael Huberman. 1992. Analisis Data Kualitatif Buku Sumber Tentang Metode-Metode Baru. Terjemahan Tjetjep Rohendi Rohidi. Jakarta: UI Press.

Muhajir Noeng. 2003. Metodologi Kualitatif. Jakarta: Raja Grafindo. masyarakat yaitu dengan memaksimalkan penggunaan website kelurahan Sumbersari mengingat masa pandemi seperti saat ini dapat mengurangi intensitas masyarakat untuk hadir dikelurahan.

Muhammad, KH Husain. 2001. Fiqih Perempuan. Yogyakarta: LkiS Yogyakarta.

Moleong, Lexy J. 2010. Metodologi Penelitian Suatu Pendekatan Edisi Revisi. Bandung: PT Remaja Rosdakarya.

Nurcholis, Hanif. 2011. Pertumbuhan dan Penyelengaraan Pemerintahan Desa. Jakarta: Erlangga.

Rivai Veithzal. 2006. Kepemimpinan dan Perilaku Politik. Jakarta: Raja Grafindo.

Sarumpaet. 2004. Wanita Teladan. Bandung: Indonesia Publishing House.

Siti Sajaroh Wiwi. 2003. Gender dalam Islam. Dalam Tim Penulis Pusat Studi Kajian 3Wanita (PSW) UIN Syarif Hidayatullah Jakarta, Pengantar Kajian Gender. Jakarta: PSW UIN Jakarta.

Siwi Utami Tari. 2001. Realitas Politik Perempuan di Indonesia. Dalam Proseding Seminar Internasional, Keterwakilan Perempuan dan Sistem Pemilihan Umum. Jakarta: National Democratic \& Meneg Pemberdayaan Perempuan RI. 
Sugiyono. 2010. Metode Penelitian Pendidikan Pendekatan Kualitatif, Kuantitatif, dan $R \& D$. Bandung: Alfabeta.

Wahjosumidjo. 1982. Kepemimpinan. Departemen P\&K, Pusat Pendidikan dan Latihan Pegawai.

PP Nomer 73 Tahun 2005 tentang kelurahan. https://ngada.org/pp73-

2005.htm.di akses pada 13 November 2020.

UUD Nomer 25 Tahun 2009 tentang pelayanan publik. https://id.wikipedia.org/wiki/U ndang-

Undang_Pelayanan_Publik.

Diakses pada 13 November 2020. 